\title{
A Screening Method for the Detection of the 35S Promoter and the Nopaline Synthase Terminator in Genetically Modified Organisms in a Real-Time Multiplex Polymerase Chain Reaction Using High-Resolution Melting-Curve Analysis
}

\author{
Hiroshi Akiyama, ${ }^{*, a}$ Fumi Nakamura, ${ }^{a}$ Chihiro Yamada, ${ }^{b}$ Kosuke Nakamura,${ }^{a}$ Osamu Nakajima, ${ }^{a}$ \\ Hiroshi KaWAKami, ${ }^{b}$ Naoki Harikai, ${ }^{c}$ Satoshi Furui, ${ }^{d}$ Kazumi Kitta, ${ }^{d}$ and Reiko Teshima ${ }^{a}$ \\ ${ }^{a}$ National Institute of Health Sciences; 1-18-1 Kamiyoga, Setagaya-ku, Tokyo 158-8501, Japan: ${ }^{b}$ Department of Food \\ Science \& Nutrition, Kyoritsu Women's University; 2-2-1 Hitotsubashi, Chiyoda-ku, Tokyo 101-8437, Japan: ' School of \\ Pharmacy and Pharmaceutical Sciences, Mukogawa Women's University; 11-68 Koshien Kyuban-cho, Nishinomiya, \\ Hyogo 663-8179, Japan: and ${ }^{d}$ National Food Research Institute; 2-1-12 Kannondai, Tsukuba, Ibaraki 305-8642, Japan. \\ Received June 19, 2009; accepted August 14, 2009; published online August 17, 2009
}

\begin{abstract}
To screen for unauthorized genetically modified organisms (GMO) in the various crops, we developed a multiplex real-time polymerase chain reaction high-resolution melting-curve analysis method for the simultaneous qualitative detection of $35 \mathrm{~S}$ promoter sequence of cauliflower mosaic virus (35SP) and the nopaline synthase terminator (NOST) in several crops. We selected suitable primer sets for the simultaneous detection of 35SP and NOST and designed the primer set for the detection of spiked ColE1 plasmid to evaluate the validity of the polymerase chain reaction (PCR) analyses. In addition, we optimized the multiplex PCR conditions using the designed primer sets and EvaGreen ${ }^{\circledR}$ as an intercalating dye. The contamination of unauthorized GMO with single copy similar to NK603 maize can be detected as low as $0.1 \%$ in a maize sample. Furthermore, we showed that the present method would be applicable in identifying GMO in various crops and foods like authorized GM soybean, authorized GM potato, the biscuit which is contaminated with GM soybeans and the rice which is contaminated with unauthorized GM rice. We consider this method to be a simple and reliable assay for screening for unauthorized GMO in crops and the processing food products.
\end{abstract}

Key words maize; nopaline synthase terminator; genetically modified organism; real-time multiplex polymerase chain reaction; high-resolution melting-curve analysis; $35 \mathrm{~S}$ promoter

In recent years, many types of genetically modified organisms (GMO), including microorganisms, animals and plants, have been put into practical use, and the number of commercially available genetically modified (GM) crops is increasing rapidly. ${ }^{1)}$ In Japan, over 70 lines of GM crops have been approved for open field cultivation or as food, feed and ornamental plants and classified as living modified organisms (LMO) under the Cartagena Protocol domestic law that came into effect in Japan on January 31, 2008.

Due to the commercialization, other GMO that have not been approved for human consumption, such as those intended for industrial processes, bioremediation, or the production of pharmaceuticals, may enter the market. Therefore, the ability to trace these organisms or to verify their absence in food will need to be assured.

GM foods have been authorized for food and/or feed by many countries based on their own criteria for safety assessment. In the EU, the authorization and use of GM foods and feed are stipulated by the provisions in regulations (EC) No. $1829 / 2003$ and (EC) No.1830/2003. ${ }^{2,3)}$ Japan also announced a mandatory safety assessment of GM foods and processed foods containing GM ingredients. Since April 1, 2001, any GM food that has not been authorized is prohibited from import or sale in Japan. Therefore, qualitative detection methods of regulated and unauthorized GM foods are required to regulate unauthorized GM food. Previously, we reported the development of qualitative detection methods for GM maize, GM potatoes (NewLeaf Plus, NewLeaf Y), GM papayas (Line 55-1 or its derivatives) and GM rice (LL rice and Chinese $\mathrm{Bt}$ rice lines), including qualitative polymerase chain re- action (PCR) methods and a histochemical assay. ${ }^{4-13)}$ Especially, in China, some GM rice varieties have been developed and tested in the field and environmental trials. ${ }^{14-16)} \mathrm{Bt}$ rice expressing the $\mathrm{Bt}$ toxin has been developed in China and approved for environmental release trials. We have detected at least two Bt rice lines, 'GM Shanyou 63' and 'Kemingdao,' which entered pre-production trails in $2001^{16,17)}$ and developed the detection methods for these rice. ${ }^{7}$

To date, no strategic method for the detection of the unauthorized GMO has been fully discussed and internationally accepted. However, to screen for unauthorized GMO in the various crops, several theoretical approaches have been proposed. One of these approaches, the "indirect subtractive approach," is based on the presumption that a positive screening test and no authorized GMO in a sample constitutes indirect evidence for the presence of unauthorized GMO. ${ }^{18)}$ In another approach, Cankar et al. reported the detection of unauthorized GMO based on differential quantitative PCR, which is an extension of qualitative differential PCR for detecting the $35 \mathrm{~S}$ promoter sequence of cauliflower mosaic virus (35SP) ${ }^{19)}$ The application of this approach has been limited to a case study of GM maize events.

While, high-resolution melting-curve analysis (HRM) is a simple and cost-effective post-PCR technique that can be used. ${ }^{20)}$ The technique requires the use of standard PCR reagents and double-stranded DNA (dsDNA)-binding dyes that are used at saturating concentrations without inhibiting PCR amplification.

In the present study, we developed a screening detection method for both $35 \mathrm{SP}$ and the nopaline synthase terminator 
(NOST) in GM crops and the processed foods using HRM with EvaGreen ${ }^{\circledR}$ as an intercalator in a real-time multiplex PCR to predictably detect unauthorized GMO.

\section{MATERIALS AND METHODS}

Samples The rice sample (imported product from China), which was suspected to be contaminated with Bt rice based on testing at a quarantine inspection center, and the biscuit, which was contaminated with GM soybean, were obtained through the Ministry of Health, Labor and Welfare (MHLW) of Japan. The biscuit consisted mainly of wheat ingredients. Rice produced in Japan was used as a negative control and was purchased commercially in Tokyo. The certified reference materials of the representative GM maize line, NK603 ( $0 \%$ (w/w, non-GM), 0.1\%, 0.5\%, 1\%, 2\% and 5\%) in powder and the representative GM soybean line, 40-3-2 (Roundup Ready Soybean) were purchased from the Institute for Reference Materials and Measurement (IRMM; Retieseweg, Belgium). GM potato (New Leaf) was kindly provided by the Monsanto Co. (St. Louis, MO, U.S.A.). The ColE1 plasmid was purchased from NIPPON GENE (Toyama, Japan).

Extraction and Purification of Genomic DNA The samples were ground using an electric mill. All the plant genomic DNA, except for the rice, was extracted using a silicagel membrane-type kit (DNeasy Plant Mini; QIAGEN, Hilden, Germany). The homogenized samples (each $1 \mathrm{~g}$ ) were incubated at $65^{\circ} \mathrm{C}$ for $10 \mathrm{~m}$ in $10 \mathrm{ml}$ of the buffer AP1 (QIAGEN) and $20 \mu \mathrm{l}$ of RNase A $(100 \mathrm{mg} / \mathrm{ml}$; QIAGEN), and mixed 2-3 times during incubation by inverting the tube. After adding buffer AP2 (QIAGEN), the resultant mixture was incubated for $10 \mathrm{~min}$ on ice. The mixture was centrifuged at $4{ }^{\circ} \mathrm{C}$ for $20 \mathrm{~min}$ at $4000 \times \mathrm{g}$. The clear supernatant was transferred to a QIA shredder spin column (QIAGEN) and centrifuged for $4 \mathrm{~min}$ at $10000 \times \mathbf{g}$. The mixture was pipetted after adding 1.5 volumes of buffer AP3/ethanol, and was applied to a mini spin column. The column was centrifuged for $1 \mathrm{~min}$ at $10000 \times \mathbf{g}$, the flow-through was discarded, and the column was washed 3 times with buffer AW (QIAGEN). The DNA was then eluted twice from the column with $70 \mu \mathrm{l}$ of the pre-warmed DW. The rice DNA extraction and purification were carried out using the NIPPON GENE GM quicker 2 kit (NIPPON GENE) according to the manufacturer's manual with the following modification. The ground samples $(500 \mathrm{mg})$ were suspended in $2.1 \mathrm{ml}$ of buffer GE1, $60 \mu \mathrm{l}$ of proteinase $\mathrm{K}(20 \mathrm{mg} / \mathrm{ml}), 6 \mu \mathrm{l}$ of $\alpha$-amylase solution (attached in kit) and $30 \mu \mathrm{l}$ of RNase A $(100 \mathrm{mg} / \mathrm{ml})$ using a vortex mixer for $30 \mathrm{~s}$ and then heated at $65^{\circ} \mathrm{C}$ for $30 \mathrm{~min}$. A $255 \mu \mathrm{l}$ aliquot of the buffer GE2-K was added to the mixture and sufficiently mixed using a vortex mixer followed by standing on ice for $10 \mathrm{~min}$. After centrifugation at $6000 \times \boldsymbol{g}$ for $15 \mathrm{~min}$ at $4{ }^{\circ} \mathrm{C}$, the collected supernatant was transferred into a new tube, and centrifuged again at $13000 \times \boldsymbol{g}$ or above at $4{ }^{\circ} \mathrm{C}$ for $5 \mathrm{~min}$. To $1 \mathrm{ml}$ of the supernatant placed in a new tube, $375 \mu$ l of both the buffer GE3 and isopropanol were added, and then the solution was gently mixed by being shaken $10-12$ times. The mixture was applied onto the spin column included in the kit and centrifuged at $13000 \times \mathrm{g}$ and $4{ }^{\circ} \mathrm{C}$ for $30 \mathrm{~s}$ to discard the eluate. This procedure was repeated until the entire eluate was loaded. The spin column was washed with $650 \mu$ of the buffer GW by centrifuging at $13000 \times \mathbf{g}$ for $1 \mathrm{~min}$. The column was transferred to a new tube and $50 \mu$ lof the TE buffer was added and allowed to stand for $3 \mathrm{~min}$ at room temperature. Finally, the tube with the spin column was centrifuged at $13000 \times \mathrm{g}$ and $4{ }^{\circ} \mathrm{C}$ for $1 \mathrm{~min}$, and the eluate was then used as the DNA sample solution in the following experiments. The extracted DNA was diluted with an appropriate volume of DW to a final concentration of $10 \mathrm{ng} / \mu \mathrm{l}$, and stored at $-20^{\circ} \mathrm{C}$ until use.

PCR Conditions The PCR reaction mixture $(25 \mu \mathrm{l})$ in the tubes contained $50 \mathrm{ng}$ genomic DNA, $2.5 \mu \mathrm{l}$ of PCR buffer II (Applied Biosystems, CA, U.S.A.), $0.16 \mathrm{~mm}$ of deoxyribonucleotide triphosphate (dNTP) (Applied Biosystems), $1.5 \mathrm{mmol} / 1 \mathrm{MgCl}_{2}, 1.2 \mu \mathrm{mol} / 1$ of $5^{\prime}$ and $3^{\prime}$ primers (P35S $1-5^{\prime}$ and P35S 2-3' for 35SP, NOS ter $3-5^{\prime}$ and NOS ter $3-3^{\prime}$ for NOST, ColE1 F1 and ColE1 R1 for ColE1), $2 \mu$ of $5 \times 10^{-2} \mathrm{pg} / \mu \mathrm{l}$ ColE1 plasmid (approximately $13.9 \times 10^{3}$ copies/reaction mixture) and 0.8 units of Ampli Taq Gold (Applied Biosystems). PCR was performed by preincubation at $95^{\circ} \mathrm{C}$ for $10 \mathrm{~min}$, followed by 45 cycles of denaturation at $95^{\circ} \mathrm{C}$ for $30 \mathrm{~s}$, annealing at $56^{\circ} \mathrm{C}$ for $30 \mathrm{~s}$, extension at $72{ }^{\circ} \mathrm{C}$ for $30 \mathrm{~s}$, and terminal elongation at $72{ }^{\circ} \mathrm{C}$ for 7 min using the GeneAmp PCR System 9700 (Applied Biosystems). After PCR amplification, the amplified products were analyzed by agarose gel electrophoresis according to the previous reports. ${ }^{4,7,9-12)}$

Multiplex Real Time PCR Using HRM The multiplex real time PCR reaction mixture $(20 \mu \mathrm{l})$ in the tubes contained 20 ng genomic DNA, 1X Multiplex PCR Mix (QIAGEN, Hilden, Germany), 0.5X Q-solution, (QIAGEN), 1X EvaGreen $^{\circledR}$ (WAKO, Tokyo, Japan), and $0.2 \mu \mathrm{mol} / 1$ of $5^{\prime}$ and $3^{\prime}$ primers (P35S $1-5^{\prime}$ and P35S 2-3' for 35SP, NOS ter 3$5^{\prime}$ and NOS ter $3-3^{\prime}$ for NOST, ColE1 F1 and ColE1 R1 for ColE1). The reaction was performed by pre-incubation at $95^{\circ} \mathrm{C}$ for $15 \mathrm{~min}$, followed by 50 cycles of denaturation at $95^{\circ} \mathrm{C}$ for $30 \mathrm{~s}$, annealing at $60^{\circ} \mathrm{C}$ for $90 \mathrm{~s}(45 \mathrm{~s}$ for uniplex real time PCR), extension at $72^{\circ} \mathrm{C}$ for $90 \mathrm{~s}$, and terminal elongation at $72{ }^{\circ} \mathrm{C}$ for $10 \mathrm{~min}$. After the latter run, the sample was held at $95^{\circ} \mathrm{C}$ for $30 \mathrm{~s}$ and then held at $72{ }^{\circ} \mathrm{C}$ for $5 \mathrm{~s}$, and melt curve data was generated by raising the temperature from 72 to $97{ }^{\circ} \mathrm{C}$ at $0.3^{\circ} \mathrm{C}$ increments, while pausing for $5 \mathrm{~s}$ per step using the Rotor gene ${ }^{\mathrm{TM}} 6000$ (QIAGEN). Positive identification of an isolate containing a gene target was determined by the corresponding melt temperature. The Rotor gene $^{\mathrm{TM}} 6000$ software (Ver 1.7) calculates melt peaks by plotting the negative first derivative of the primary melt curve (fluorescence $v s$. temperature).

\section{RESULTS}

Design of the PCR Systems and the Selection of EvaGreen $^{\circledR}$ as an Intercalator Dye We selected primers that were appropriate for the simultaneous detection of 35SP and NOST in screening for unauthorized GMO. In addition, we further designed the primers to detect ColE1 spiked to assess the validity of the PCR run. ${ }^{21)}$ The selected primer pairs are described in Table 1. Selection of primers was performed on the basis of the results obtained from conventional PCR and electrophoresis using the NK603 maize sample. Electrophoresis analysis showed no formation of primer dimers 
(Fig. 1). Next, we examined SYBR ${ }^{\circledR}$ Green I and EvaGreen ${ }^{\circledR}$ as intercalating dyes. Both fluorescence dyes provided similar amplification and melting curve data, although the shape of the melting curve using EvaGreen ${ }^{\circledR}$ was detected more

Table 1. Primer Sequences and Product Tm for the Multiplex Real Time PCR

\begin{tabular}{llcl}
\hline \hline \multicolumn{1}{c}{ Name } & Oligonucleotide sequence & $\begin{array}{c}\text { Product } \\
\text { Tm }\left({ }^{\circ} \mathrm{C}\right)\end{array}$ \\
\hline P35S 1-5' & ATT GAT GTG ATA TCT CCA CTG ACG T & 80.18 \\
P35S 2-3' & CCT CTC CAA ATG AAA TGA ACT TCC T & 80.18 \\
NOS ter 3-5' & GTC TTG CGA TGA TTA TCA TAT AAT TTC TG & 77.09 \\
NOS ter 3-3' & CGC TAT ATT TTG TTT TCT ATC GCG T & 77.09 \\
ColE1 F1 & CGG TTA CTT GAA CGC TGT GA & 90.59 \\
ColE1 R1 & CAC CTT ACG GGC TGT CTG AT & 90.59 \\
\hline
\end{tabular}

clearly (data not shown). Considering the reliability and sensitivity of the analysis, we chose to use EvaGreen ${ }^{\circledR}$ in further experiments.

In uniplex PCR, the specific amplification of either 35SP, NOST or ColE1 was performed on the NK603 maize and ColE1 plasmid. All sequences were correctly identified as possessing the correct sequence for each primer set as observed by distinct melt peaks at specific temperatures. Melt peak height and shape were consistent for each sequence target. Melt temperatures relative to one another were in agreement with the expected amplicon size, with larger amplicons exhibiting higher Tms. Non-GM rice sample was considered negative due to the melt profiles.

Multiplex PCR Systems We examined the suitability of the proposed real-time PCR systems to be used in a Tm melting curve determination. After careful analysis of the respec-
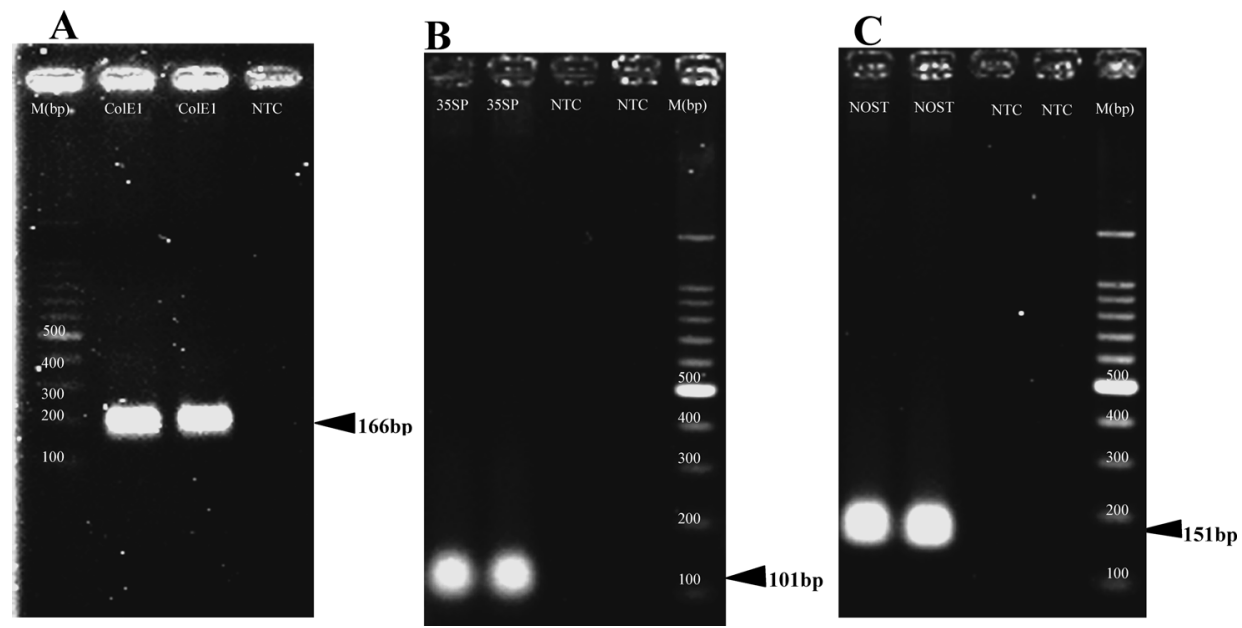

Fig. 1. Targeted Gene Amplification by PCR

PCR reactions were run using total genomic DNA from GM maize line (NK603) as the template and primers that were designed specific to ColE1 (A), 35SP (B) and NOST (C), and analyzed by $3 \%(\mathrm{w} / \mathrm{v})$ agarose gel electrophoresis in TAE buffer. Arrows indicate the amplified PCR products stained by ethidium bromide. NTC, non-template control; M, 100 bp DNA marker.
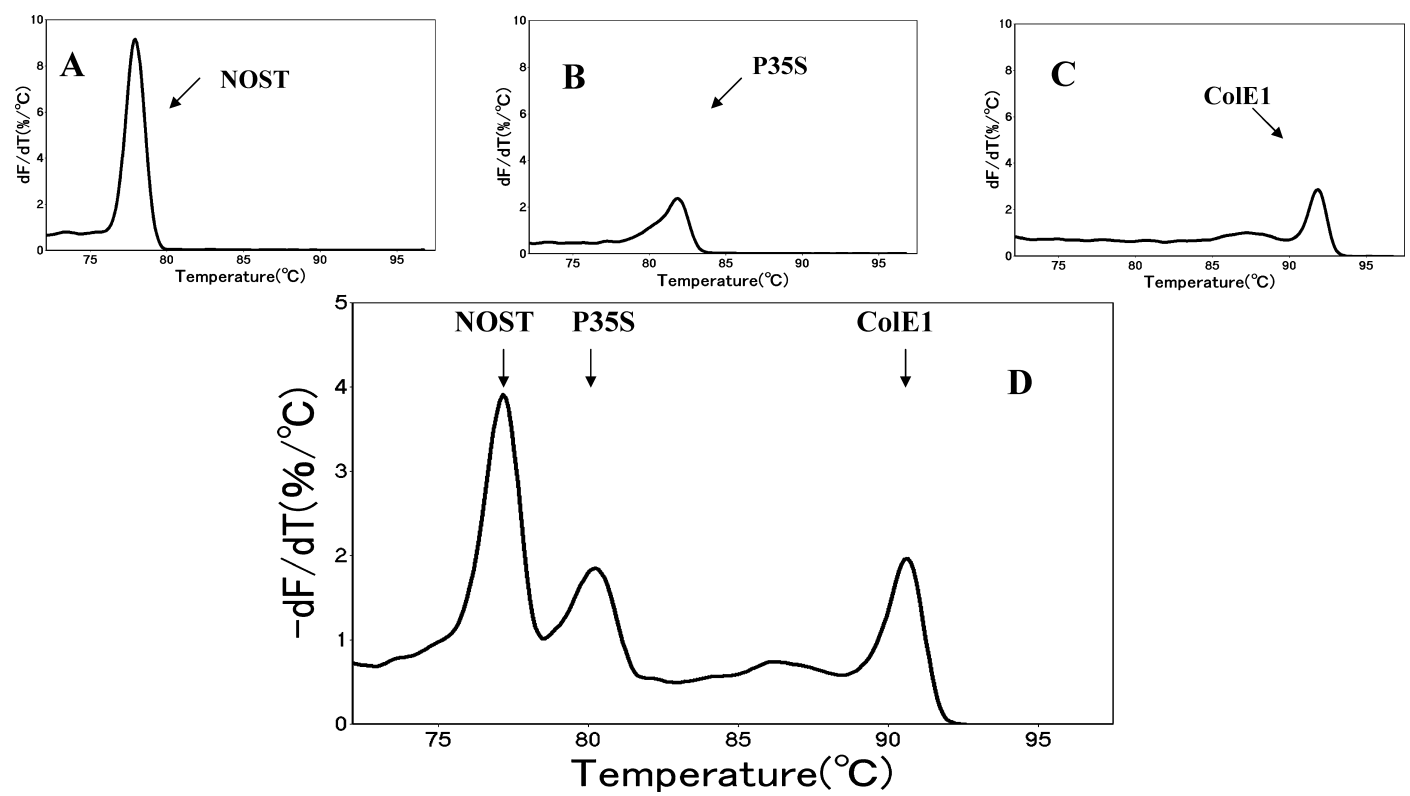

Fig. 2. Melting Curve of Each Uniplex PCR Assay for NOST (A), P35S (B), ColE1(C) and 3-Plex PCR Assay (D)

NK603 maize genomic DNA was amplified as the template by thermal conditions (initial denaturation at $95^{\circ} \mathrm{C}$ for $15 \mathrm{~m}$, followed by 50 cycles of denaturation at $95^{\circ} \mathrm{C}$ for $30 \mathrm{~s}$, annealing at $60^{\circ} \mathrm{C}$ for $90 \mathrm{~s}$ and extension at $72^{\circ} \mathrm{C}$ for $90 \mathrm{~s}$, and terminal elongation at $72{ }^{\circ} \mathrm{C}$ for $10 \mathrm{~min}$ ). Melting curves were analyzed by Rotor gene ${ }^{\mathrm{TM}} 6000$ using EvaGreen ${ }^{\circledR}$ as an intercalating dye, and the corresponding $\mathrm{Tm}$ was assigned to each product by arrow. 
tive experimental Tm, we optimized the PCR conditions in the multiplex condition using the NK603 maize sample. In particular, we examined the time of the annealing step since that step is critical for the optimization of the multiplex condition. We found that $90 \mathrm{~s}$ was the optimal time for annealing in the multiplex format. Multiplex reactions using the 3 primer sets in the same reaction tube showed positive melting curves in the sample solution prepared from NK603 maize sample. For the examination of the level of spiked ColE1, we found that the optimized level of the spiked ColE1 is approximately, $2 \mu \mathrm{l}$ of $5 \times 10^{-2} \mathrm{pg} / \mu \mathrm{l}$ ColE1 plasmid (approximately $13.9 \times 10^{3}$ copies $)$ in the PCR reaction mixture $(25 \mu \mathrm{l})$.

The Tm of the melt curve profile can identify which target sequences were amplified by PCR (Fig. 2). Peaks were clearly separated from one another and the average Tms of the different peaks were significantly different in the multiplex reaction. On the other hand, no significant shifts of the average Tms of 35SP, NOST and ColE1 were observed between the uniplex and multiplex reactions. The sample solu- tion prepared from non-GM maize did not produce the correct amplicon when viewed on agarose gels and did not show the correct melt profiles.

To assess the sensitivity of the proposed method using the NK603 maize samples, we tested different amounts of the NK603 maize samples: 0\% (non-GM), 0.1\%, 0.5\%, 1\%, 2\% and $5 \%$. As shown in Fig. 3, all of the positive melting curves were obtained stably except for the $0 \%$ sample. These results suggest that the contamination of unauthorized GMO with single copy of the transgenic gene similar to NK603 maize as low as $0.1 \%$ can be detected in a maize sample.

Application to Various Other Samples To assess the application of the established method to other crops, the authorized GM soybean (Roundup Ready Soybean), the authorized GM potato (NewLeaf), the biscuit which is contaminated with GM soybean and the rice which is contaminated with unauthorized GM rice were analyzed using the established method. As shown in Fig. 4, the positive melting curves for $35 \mathrm{~S}$ and NOST were detected in GM soybean,
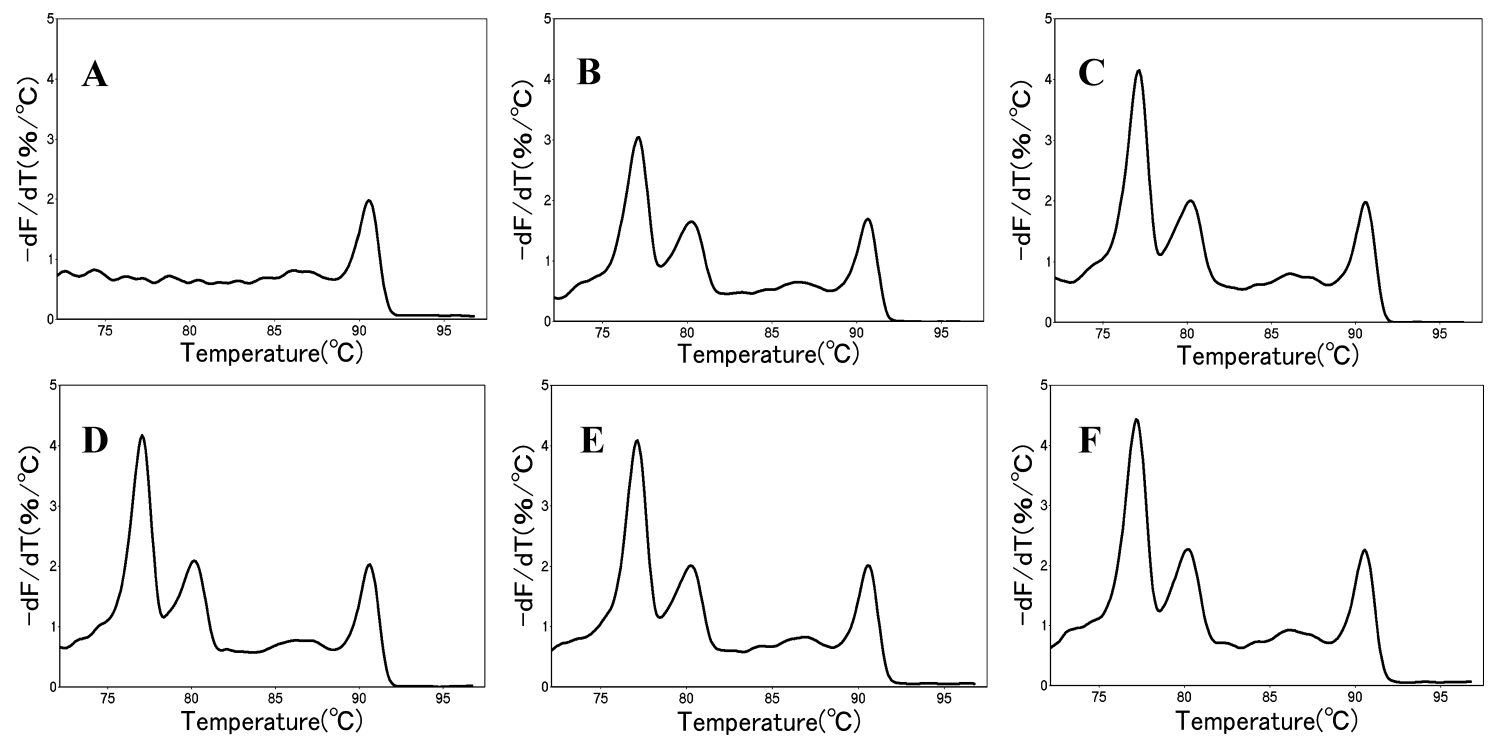

Fig. 3. Sensitivity of the 3-Plex Realtime PCR

The melting curves were tested for detection of different amounts of NK603 maize samples: A) $0 \%(w / w$, non-GM), B) $0.1 \%(w / w), C) 0.5 \%(w / w), D) 1 \%(w / w), E) 2 \%(w / w)$ and F) $5 \%(w / w)$.
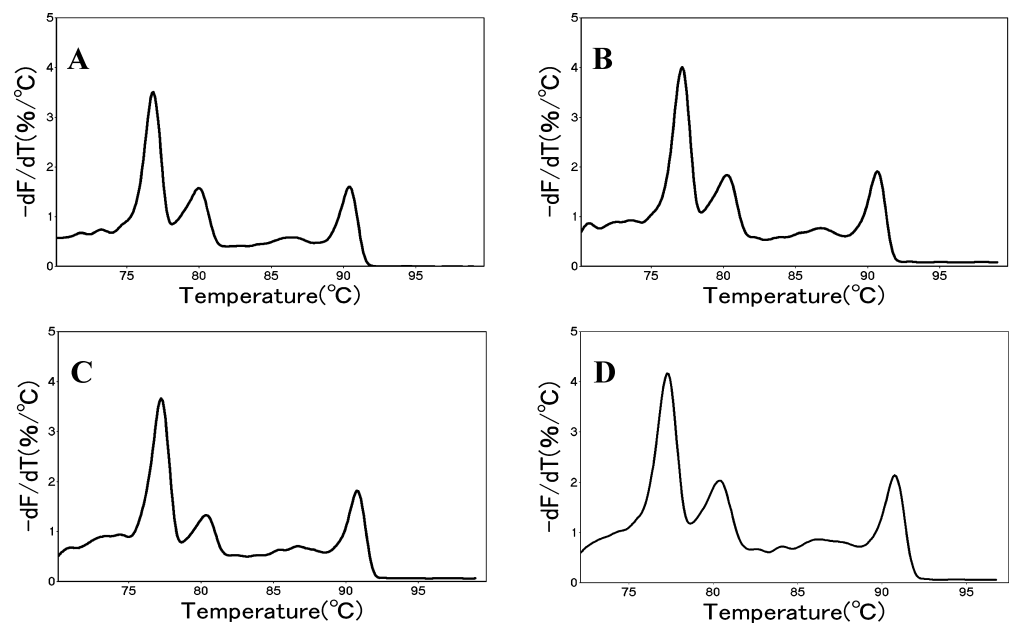

Fig. 4. Application to Other GM Products for Detection

Melting curves represent 3-plex PCR using total genomic DNA samples from: A) GM soybean (Roundup Ready Soybean), B) GM potato (NewLeaf), C) rice contaminated with unauthorized GM rice and D) biscuit contaminated with GM soybean of unknown amount. 
GM potato, the biscuit which is contaminated with GM soybean and the rice which is contaminated with unauthorized GM rice. The melt profiles did not produce peaks, except for ColE1 as a reference, in non-GM soybean, non-GM rice and non-GM potato as negative samples (data not shown). These results suggest that the method established here may be applicable in identifying GMO in various crops and foods.

\section{DISCUSSION}

A simultaneous qualitative detection method for 35SP and NOST using HRM was developed for the screening detection of unauthorized GMO in several crops. We selected suitable primer sets for the simultaneous detection of 35SP and NOST and designed the primer set for the detection of spiked ColE1 plasmid to evaluate the validity of the PCR analyses. In addition, we optimized in the multiplex PCR conditions using the designed primer sets and EvaGreen ${ }^{\circledR}$ as an intercalating dye. We considered that using EvaGreen ${ }^{\circledR}$ would be more accurate because EvaGreen ${ }^{\circledR}$ is a generally less inhibitory toward PCR and less likely to cause nonspecific amplification compared with SYBRGreen $\mathrm{I}^{\circledR}$.

Simple and accurate screening methods for detection are necessary to search the unauthorized GM crops in various foods. Many studies have employed PCR to target multiple genes for the detection of GM crops. However, conventional PCR requires post-PCR processing to visualize the amplification products, and usually including agarose gel electrophoresis and nucleic acid staining. The handling of PCR products is not only time-consuming, but also has the potential of cross-contamination of the amplified products. Realtime PCR has solved many of these problems, allowing faster cycling times and closed-tube detection during the amplification process. Previous studies have demonstrated the detection of GM crops using specific probes. ${ }^{7,13)}$ However, the use of fluorescence labeled probes adds significant cost to an assay comprising multiple targets. The closed-tube screening method using HRM has advantages over current techniques because it requires no post-PCR handling, which minimize the risk of PCR contamination, and no separation step, both of which improve analysis time.

The intercalating dyes, such as SYBR ${ }^{\circledR}$ Green I and EvaGreen $^{\circledR}$, have been used successfully in real-time PCR HRM. $^{22-24)}$ They bind all amplified dsDNA and do not confer sequence specificity to a desired target as oligonucleotide probes. However, the amplicons can be distinguished by melt curve analysis, whereby the melting temperature of PCR products is determined by the reduction in relative fluorescence as all dsDNA is denatured to the single-stranded form. The shape and peak location of the melt curve are functions of the GC/AT ratio, length, and sequence of the fragment. ${ }^{23}$ ) Therefore, optimized reaction conditions and sufficient differences in amplicon length and GC/AT ratio are necessary to discriminate clearly between amplification products in a melt analysis. A real-time PCR HRM using EvaGreen ${ }^{\circledR}$ was developed to simultaneously detect 35SP, NOST and ColE1. Each product differed sufficiently in size and sequence to be distinguished by melt curve analysis and agarose gel electrophoresis.

In addition, we applied the method established in this study to several GM crops. To assess unauthorized GM crop contamination, GM maize, GM soybean, GM rice and the biscuits contaminated with GM soybeans were used as selected targets. We showed that the present method is applicable for GM maize, GM soybean, GM rice and even the detection of GM soybean in the biscuit, which consisted mainly of wheat. The present method has the potential to screen for novel types of unauthorized GM crops, as well as authorized GM crops, since 35SP and NOST are major sequences in GM crops and widely inserted into various GM crops.

Recently, we detected unauthorized GM crops that have become major concerns such as $\mathrm{CBH} 351$ maize, Bt10 maize, LLRice601, and Chinese Bt rice. The present method may not meet the absolute detection limit of unauthorized GM crops, because the contaminated crops may contain unknown recombinant-DNA (r-DNA) sequence or r-DNA sequences with modified nucleotide sequences. However, after confirming the contamination of unauthorized GM crops using the present method, it may be necessary to analyze the detailed construct sequence close to 35SP and NOST using inversed PCR and anchored PCR techniques.

In conclusion, we developed a multiplex real-time PCR HRM method for the simultaneous qualitative detection of 35SP and NOST in several crops. We consider this method to be a simple and reliable assay for screening for unauthorized GMO in crops and the processing food products.

Acknowledgments Hiroshi Akiyama and Fumi Nakamura contributed equally to this work. We would like to thank Monsanto Company for providing GM potato (NewLeaf). We thank Mr. Hiroaki Yamamoto, QIAGEN Co. for teaching us the technique of HRM and for providing useful suggestions. This study was supported by the Health and Labor Sciences Research Grants of the Research on Food Safety from the Ministry of Health, Labor, and Welfare of Japan.

\section{REFERENCES AND NOTES}

1) James C., ISAAA Briefs 2008, 2008, 39 (2008).

2) "Regulation (EC) No. 1829/2003 of the European Parliament and of the Council of 22 September 2003 on Genetically Modified Food and Feed," Off. J. Eur. Commun., L268, 2003, pp. 1-23.

3) "Regulation (EC) No. 1830/2003 of the European Parliament and of the Council of 22 September 2003 Concerning the Traceability and Labelling of Genetically Modified Organisms and the Traceability of Food and Feed Products Produced from Genetically Modified Organisms and Amending Directive 2001/18/EC," Off. J. Eur. Commun., L268, 2003, pp. 24-28.

4) Wakui C., Akiyama H., Watanabe T., Fitch M. M., Uchikawa S., Ki M., Takahashi K., Chiba R., Fujii A., Hino A., Maitani T., Shokuhin Eiseigaku Zasshi, 45, 19-24 (2004).

5) Matsuoka T., Kawashima Y., Akiyama H., Miura H., Goda Y., Sebata T., Isshiki K., Toyoda M., Hino A., Shokuhin Eiseigaku Zasshi, 40, 149-157 (1999).

6) Matsuoka T., Kuribara H., Takubo K., Akiyama H., Miura H., Goda Y., Kusakabe Y., Isshiki K., Toyoda M., Hino A., J. Agric. Food Chem., 50, 2100-2109 (2002).

7) Akiyama H., Sasaki N., Sakata K., Ohmori K., Toyota A., Kikuchi Y., Watanabe T., Furui S., Kitta K., Maitani T., J. Agric. Food Chem., 55, $5942-5947$ (2007)

8) Matsuoka T., Kuribara H., Suefuji S., Miura H., Kusakabe Y., Akiyama H., Goda Y., Isshiki K., Toyoda M., Hino A., Shokuhin Eiseigaku Zasshi, 42, 197-201 (2001).

9) Akiyama H., Watanabe T., Wakui C., Chiba Y., Shibuya M., Goda Y., Toyoda M., Shokuhin Eiseigaku Zasshi, 43, 301-305 (2002).

10) Akiyama H., Sugimoto K., Matsumoto M., Isuzugawa K., Shibuya M., 
Goda Y., Toyoda M., Shokuhin Eiseigaku Zasshi, 43, 24-29 (2002).

11) Goda Y., Asano T., Shibuya M., Hino A., Toyoda M., Shokuhin Eiseigaku Zasshi, 42, 231-236 (2001).

12) Watanabe T., Shiramasa Y., Furui S., Kitta K., Minegishi Y., Akiyama H., Maitani T., Shokuhin Eiseigaku Zasshi, 48, 170-178 (2007).

13) Watanabe T., Tokishita S., Spiegelhalter F., Furui S., Kitta K., Hino A., Matsuda R., Akiyama H., Maitani T., J. Agric. Food Chem., 55, 1274-1279 (2007).

14) Datta K., Baisakh N., Thet K. M., Tu J., Datta S. K., Theor. Appl. Genet., 106, 1-8 (2002).

15) Huang J., Hu R., Rozelle S., Pray C., Science, 308, 688-690 (2005).

16) Tu J., Zhang G., Datta K., Xu C., He Y., Zhang Q., Khush G. S., Datta S. K., Nat. Biotechnol., 18, 1101-1104 (2000).

17) Pray C. E., Ramaswami B., Bengali P., Zhang H., Int. J. Tech. Glob., 2, $137-157$ (2006).
18) Aarts H. J., van Rie J. P., Kok E. J., Expert Rev. Mol. Diagn., 2, 69-76 (2002).

19) Cankar K., Chauvensy-Ancel V., Fortabat M. N., Gruden K., Kobilinsky A., Zel J., Bertheau Y., Anal. Biochem., 376, 189-199 (2008).

20) Yoshitomi K. J., Jinneman K. C., Weagant S. D., Mol. Cell. Probes, 20, $31-41$ (2006).

21) Harikai N., Saito S., Abe M., Kondo K., Kitta K., Akiyama H., Teshima R., Kinoshita K., Biosci. Biotechnol. Biochem., 72, 29532958 (2008).

22) Lipsky R. H., Mazzanti C. M., Rudolph J. G., Xu K., Vyas G., Bozak D., Radel M. Q., Goldman D., Clin. Chem., 47, 635-644 (2001).

23) Ririe K. M., Rasmussen R. P., Wittwer C. T., Anal. Biochem., 245, 154-160 (1997).

24) Wittwer C. T., Herrmann M. G., Moss A. A., Rasmussen R. P., Biotechniques, 22, 130-131, 134-138 (1997). 